\title{
Article \\ Development and Properties of Francisella tularensis Subsp. holarctica 15 NIIEG Vaccine Strain without the recD Gene
}

\author{
Vitaly Pavlov*(D), Galina Vakhrameeva, Alexander Mokrievich, Mikhail E. Platonov, Galina Titareva, \\ Raisa Mironova, Tatiana Kombarova, Tatiana Gapelchenkova and Ivan Dyatlov
}

\section{check for}

updates

Citation: Pavlov, V.; Vakhrameeva,

G.; Mokrievich, A.; Platonov, M.E.;

Titareva, G.; Mironova, R.;

Kombarova, T.; Gapelchenkova, T.;

Dyatlov, I. Development and

Properties of Francisella tularensis

Subsp. holarctica 15 NIIEG Vaccine

Strain without the $r e c D$ Gene.

Vaccines 2022, 10, 108. https://

doi.org/10.3390/vaccines10010108

Academic Editor: Tohru Suzuki

Received: 19 November 2021

Accepted: 28 December 2021

Published: 11 January 2022

Publisher's Note: MDPI stays neutral with regard to jurisdictional claims in published maps and institutional affiliations.

Copyright: (C) 2022 by the authors. Licensee MDPI, Basel, Switzerland. This article is an open access article distributed under the terms and conditions of the Creative Commons Attribution (CC BY) license (https:// creativecommons.org/licenses/by/ $4.0 /)$.
State Research Center for Applied Microbiology and Biotechnology (SRCAMB), 142279 Obolensk, Russia; vahrameeva@obolensk.org (G.V.); mokrievich@obolensk.org (A.M.); platonov@obolensk.org (M.E.P.); titareva@obolensk.org (G.T.); mironovari@obolensk.org (R.M.); kombarova@obolensk.org (T.K.); gapelchenkova@obolensk.org (T.G.); dyatlov@obolensk.org (I.D.)

* Correspondence: vitpav@obolensk.org; Tel.: +74-967360063

\begin{abstract}
The genomic analysis of all subspecies F. tularensis, as found in Gen Bank NCBI, reveals the presence of genes encoding proteins like to the multifunctional RecBCD enzyme complex in E. coli and other bacteria. To date, the role of the recD gene in F. tularensis, which encodes the alpha chain of exonuclease V, in DNA metabolism processes, has not been studied either in vitro or in vivo. F. tularensis subsp. holarctica 15 NIIEG, a vaccine strain, served as the basis to create the F. tularensis $15 \mathrm{D}$ strain with $r e c D$ deletion. The lack of the $r e c D$ gene suppresses the integration of suicide plasmids with F. tularensis genome fragments into the chromosome. The modified strain showed reduced growth in vitro and in vivo. This study shows that such deletion significantly reduces the virulence of the strain in BALB/c mice.
\end{abstract}

Keywords: Francisella tularensis 15 NIIEG; recD gene; allelic exchange; in vitro and in vivo reproduction; $\mathrm{BALB} / \mathrm{c}$ mice

\section{Introduction}

Tularemia is an acute infectious disease in humans and animals that is etiologically caused by the bacteria Francisella tularensis; humans' high susceptibility to the pathogen makes this disease extremely dangerous for subspecies of F. tularensis subsp. tularensis (mortality rate of up to $60 \%$ in untreated cases) [1,2]. To prevent tularemia, endemic areas of Russia use a live vaccine based on the F. tularensis subsp. holarctica 15 NIIEG strain [3]. In Western Europe and North America, they use a live vaccine based on an F. tularensis LVS (live vaccine strain) in case of an emergency, which is obtained by a series of passages of $F$. tularensis 15 in vitro [4]. Both vaccine strains of $F$. tularensis have several weaknesses. The vaccine based on the 15 NIIEG strain causes adverse reactions in $6-10 \%$ of vaccinated patients [5]. The LVS strain has the same shortcomings: besides reactogenicity, the culture exhibits some dissociation during culturing [6,7]. All of this prevents the FDA from licensing a live tularemia vaccine in the USA [8].

Homologous recombination involving products of the rec $A$ gene and the multifunctional RecBCD enzyme complex is one of the factors affecting the stability of the bacterial genome [9]. The genomes of the genus Francisella contain regions encoding the RecBCD enzyme complex like to the structure of the region encoding the $E$. coli RecBCD enzyme complex. The amino acid sequence of the E. coli RecD protein has $40 \%$ similarity and $27 \%$ identity compared to the sequence of the RecD protein of F. tularensis subsp. holarctica. In the LVS and 15 NIIEG strains, the $r e c D$ gene forms a single operon with the recB (FTL_0669) gene; genes $r e c B D$ and $r e c C\left(F T L \_0666\right)$ are separated by an intergenic region of 71 bp [Gen Bank NCBI, CP009694.1] (Supplementary S1). 
The genomes of all F. tularensis subspecies have a recD-like nucleotide sequences: FTL_0670 [Gen Bank NCBI, CP009694.1] in holarctica, FTM_0631 [Gen Bank NCBI, CP000915.1] in mediasiatica, [Gen Bank NCBI, AJ749949.2] in tularensis.

The role of recD in $F$. tularensis in DNA metabolism and reproduction in vitro and in vivo remains unclear. Here, we describe the construction of F. tularensis 15 NIIEG strain without $r e c D$ gene and further research of its properties. $r e c D$ deletion significantly reduces the ability to integrate suicide plasmids with $F$. tularensis genome fragments and the bacteria growth in vitro. Complementation of the deletion restores the molecular and biological properties of the modified strain.

\section{Materials and Methods}

Bacterial strains, plasmids, and primers. Bacterial strains and plasmids used in this study are listed in Table 1. The primers for synthesis and control of the modified regions of the F. tularensis genome are listed in Table 2.

Table 1. Bacterial strains and plasmids used in this research.

\begin{tabular}{|c|c|c|}
\hline Name & Description & Source or Reference \\
\hline \multicolumn{3}{|c|}{ Strains } \\
\hline E. coli $\mathrm{DH} 5 \alpha$ & $\begin{array}{c}F^{-}(\varphi 80 \text { dlacZ } \triangle M 15) \text { recA1 endA1 gyrA96 thi-1 hsdR17 }\left(r_{k}{ }^{-} m_{k}{ }^{+}\right) \\
\text {supE44 relA1 deoR } \Delta(\text { lacZYA-argF) U169 }\end{array}$ & GKPM-Obolensk * [10] \\
\hline E. coli S17-1 $\lambda$ pir & (thi pro hsdR-hsdM+ recA RP4-2-Tc::Mu-Km::Tn7(TpR SmR)) & GKRM-Obolensk [11] \\
\hline E. coli $\mathrm{S} 17(\mathrm{pHVmob})$ & $\begin{array}{c}\mathrm{Amp}^{\mathrm{R}}, \mathrm{Cm}^{\mathrm{R}} \text {, a derivative of } \mathrm{S} 17-1 \lambda \text { pir containing } \mathrm{pHVmob} \\
\text { plasmid }\end{array}$ & This paper \\
\hline E. coli $\mathrm{DH} 5 \alpha(\mathrm{pGM} \Delta \mathrm{recD})$ & $\mathrm{Amp}^{\mathrm{R}}, \mathrm{Cm}^{\mathrm{R}}$, Suc ${ }^{\mathrm{S}}$, derivative of $\mathrm{DH} 5 \alpha, \mathrm{pGM} \Delta \mathrm{recD}$ plasmid & This paper \\
\hline E. coli DH5 $\alpha$ (pUK194) & $\begin{array}{c}A m p^{R} \mathrm{Km}^{\mathrm{R}} \text { derivative of } \mathrm{DH} 5 \alpha \text { containing pUK194 } \\
\text { plasmid }\end{array}$ & This paper \\
\hline E. coli $\mathrm{DH} 5 \alpha(\mathrm{pUK} / \mathrm{recD})$ & $\begin{array}{l}\text { Amp }{ }^{\mathrm{R}} \mathrm{Km}^{\mathrm{R}} \text { derivative of } \mathrm{DH} 5 \alpha \text { with pUK194 plasmid, a } \\
\text { fragment of the } F \text {. tularensis genome with the recD gene }\end{array}$ & This paper \\
\hline E. coli DH5 $\alpha(\mathrm{pGM} \Delta \mathrm{sodC})$ & $\begin{array}{c}\mathrm{Amp}^{\mathrm{R}}, \mathrm{Cm}^{\mathrm{R}}, \mathrm{Suc}^{\mathrm{S}}, \text { derivative of } \mathrm{DH} 5 \alpha \text { containing } \\
\mathrm{pGM} \Delta \text { sodC plasmid }\end{array}$ & This paper \\
\hline E. coli $\mathrm{S} 17(\mathrm{pPV} \Delta \mathrm{glC})$ & $\begin{array}{c}\mathrm{Amp}^{\mathrm{R}}, \mathrm{Cm}^{\mathrm{R}}, \mathrm{Suc}^{\mathrm{S}} \text {, derivative of } \mathrm{S} 17-1 \text { ipir containing } \\
\text { pPV } \Delta \text { iglC plasmid, }\end{array}$ & GKRM-Obolensk [11] \\
\hline F. tularensis 15 NIIEG & $\mathrm{Pm}^{\mathrm{R}}, \mathrm{Amp}^{\mathrm{R}}$, subsp. holarctica, a vaccine strain & GKPM-Obolensk \\
\hline F. tularensis 15D & $\begin{array}{l}\mathrm{Pm}^{\mathrm{R}} \text {, a modified F. tularensis } 15 \text { NIIEG strain with the } \\
\text { recDgene deleted }\end{array}$ & This paper \\
\hline F. tularensis $15 \mathrm{D}(\mathrm{pHVmob})$ & $\mathrm{Pm}^{\mathrm{R}}, \mathrm{Cm}^{\mathrm{R}}$ F. tularensis 15D with $\mathrm{pHVmob}$ plasmid & This paper \\
\hline F. tularensis 15(pK194) & $\mathrm{Km}^{\mathrm{R}}$, a F. tularensis 15 NIIEG strain with pK194 plasmid, & This paper \\
\hline F. tularensis 15D(pUK194) & $\mathrm{Pm}^{\mathrm{R}}$, a F. tularensis 15D strain with pUK194 plasmid & This paper \\
\hline F. tularensis $15 \mathrm{D}(\mathrm{pUK} / \mathrm{recD})$ & $\begin{array}{c}\mathrm{Pm}^{\mathrm{R}} \text {, a F. tularensis } 15 \mathrm{D} \text { with } \mathrm{pUK} / \mathrm{recD} \text { plasmid containing } \\
\text { a fragment of the F. tularensis genome with the recD gene } \\
\text { Plasmids }\end{array}$ & This paper \\
\hline pC194 & $\mathrm{Cm}^{\mathrm{R}}$. Replicates autonomously in F. tularensis cells & [12-14] \\
\hline pHV33 & $A m p^{R}, \mathrm{Cm}^{\mathrm{R}}$ & [15] \\
\hline $\mathrm{pHVmob}$ & $\begin{array}{c}\mathrm{Amp}^{\mathrm{R}}, \mathrm{Cm}^{\mathrm{R}}, \mathrm{pHV} 33 \text { plasmid containing a } 1.7-\mathrm{kb} \text { fragment } \\
\text { of RP4 plasmid with a mob region }\end{array}$ & This paper \\
\hline pGM5 & $\mathrm{Amp}^{\mathrm{R}}, \mathrm{Cm}^{\mathrm{R}}, \mathrm{sacB}$. & [16] \\
\hline $\mathrm{pGM} \Delta \mathrm{recD}$ & $\begin{array}{l}\mathrm{Amp}^{\mathrm{R}}, \mathrm{Cm}^{\mathrm{R}} \text {, sacB, pGM5 plasmid with a modified } 2.9-\mathrm{kb} \\
\text { fragment of the F. tularensis } 15 \text { NIIEG genome, } 603 \mathrm{bps} \\
\text { deleted from the recD gene }\end{array}$ & This paper \\
\hline pK194 & $\begin{array}{l}\mathrm{Km}^{\mathrm{R}} \text {, derivative of pC194 plasmid with the cat gene } \\
\text { replaced by } \mathrm{Km}^{\mathrm{R}} \text { from the mTn10Km transposon. } \\
\text { Replicates autonomously in F. tularensis cells }\end{array}$ & This paper \\
\hline pUC19 & $A m p^{R}$ & [17] \\
\hline
\end{tabular}


Table 1. Cont.

\begin{tabular}{|c|c|c|}
\hline Name & Description & Source or Reference \\
\hline pUK194 & $\begin{array}{c}A m p^{R} \mathrm{Km}^{\mathrm{R}} \text { cointegrate of pUC19 and pK194 plasmids at } \\
\text { the HindIII site. }\end{array}$ & This paper \\
\hline $\mathrm{pUK} / \mathrm{rec} D$ & $\begin{array}{l}A m p^{\mathrm{R}} \mathrm{Km}^{\mathrm{R}} \text {, pUK194 plasmid with a } 3.5-\mathrm{kb} \text { fragment of the } \\
\text { F. tularensis genome containing the recD gene }\end{array}$ & This paper \\
\hline $\mathrm{pPV} \Delta \mathrm{iglC}$ & $\begin{array}{l}A m p^{\mathrm{R}}, \mathrm{Cm}^{\mathrm{R}}, \text { sacB, } \mathrm{pPV} \text { plasmid with a } 3.0-\mathrm{kb} \text { fragment of } \\
\text { the F. tularensis } 15 \text { NIIEG genome, } 545 \text { bps deleted from the } \\
\text { iglC gene }\end{array}$ & [11] \\
\hline $\mathrm{pGM} \Delta \operatorname{sodC}$ & $\begin{array}{c}\mathrm{Amp}^{\mathrm{R}}, \mathrm{Cm}^{\mathrm{R}}, \mathrm{sacB}, \mathrm{pGM} 5 \text { plasmid with a modified } 1.7-\mathrm{kb} \\
\text { fragment of the F. tularensis } 15 \text { NIIEG genome, } 528 \mathrm{bps} \\
\text { deleted from the sodC gene }\end{array}$ & This paper \\
\hline
\end{tabular}

* GKPM-Obolensk stands for the State Collection of Pathogenic Microorganisms and Cell.

Table 2. Primers used in this research.

\begin{tabular}{|c|c|c|}
\hline Name & Sequence $5^{\prime}-3^{\prime} a, b$ & Primer Localization \\
\hline & \multicolumn{2}{|l|}{ For $r e c D$ deletion } \\
\hline FSD & AAAgtcgacTGGCAAAGATGATAGTGT & forward primer with a SalI site \\
\hline RBD & $\begin{array}{l}\text { AAAggatccTTACATAGACGGAGTAGTCT } \\
\text { Amplicon downstream the recD gene }\end{array}$ & reverse primer with a BamHI site \\
\hline FBD & AAAggatccTAAGCTCAGAGAATGACAGA & forward primer with a BamHI site \\
\hline \multicolumn{3}{|c|}{ Amplicon to control rec $D$ deletion } \\
\hline FCD & GATGGTTATGGAGTTTATCGAGC & forward primer \\
\hline $\mathrm{RCD}$ & TAAGAGCCTCTTTGTAGTCACGG & reverse primer \\
\hline \multicolumn{3}{|c|}{ For sodC deletion } \\
\hline sodCL-F & AAAgtcgacAACGACAGCATATTGCCACTCATAG & forward primer with a SalI site \\
\hline \multicolumn{3}{|c|}{ Amplicon downstream the sodC gene } \\
\hline sodCR-F & AAAggatccGTGCTAGAATGTGGTGTGGAGTTA & forward primer with a BamHI site \\
\hline sodCR-R & AAAgtcgacCATATCAATATGACCTTTCTTTGGC & reverse primer with a SalI site \\
\hline \multicolumn{3}{|c|}{ Amplicon to control sodC deletion } \\
\hline sodC-KF & CGTATCAGCTAAAGTGATAATCGGT & forward primer \\
\hline sodC-KR & GACAAAATACTGCAACACCAACAGC & reverse primer \\
\hline
\end{tabular}

Culture conditions. F. tularensis strains were grown at $37^{\circ} \mathrm{C}$ in FT agar: per $1 \mathrm{~L}$ : fish meal hydrolysate $16 \mathrm{~g}$, enzymatic lysate of cattle blood $4 \mathrm{~g}$, a mixture of B vitamins $0.014 \mathrm{~g}$, calcium pantothenate $0.014 \mathrm{~g}$, magnesium sulfate $0.45 \mathrm{~g}$, sodium sulphite $0.65 \mathrm{~g}$, cysteine $0.4 \mathrm{~g}$, glucose $6 \mathrm{~g}$, agar $10 \mathrm{~g}$, pH 7.2 (manufactured by the department of nutrient media SRCAMB), chocolate agar [18], or in brain heart infusion broth (BHI) (Becton-Dickinson, Franklin Lakes, NJ, USA), and FTB broth: per one 1-5 g of casein acid hydrolysate, $5 \mathrm{~g}$ of yeast extraction, $12 \mathrm{~g}$ of monopotassium phosphate, $3.9 \mathrm{~g}$ of potassium hydroxide, $10 \mathrm{~g}$ of sodium chloride, $0.1 \mathrm{~g}$ of cysteine hydrochloride monohydrate, $6 \mathrm{mg}$ of iron II sulfate heptahydrate, $2 \mathrm{~g}$ of glucose, $\mathrm{pH}$ 7.2. The cultivation was carried out in flasks on a thermostated shaker, $200 \mathrm{rpm}$, or in the plate wells on the shaker Multiscan FC unit (Thermo scientific, Singapore). When required, polymyxin B $(100 \mu \mathrm{g} / \mathrm{mL})$, chloramphenicol $(3 \mu \mathrm{g} / \mathrm{mL})$, kanamycin $(20 \mu \mathrm{g} / \mathrm{mL})$, or sucrose $(10 \%)$ was added to media. Bacterial inocula for animal infection studies was generated by streaking F. tularensis strains onto FT plates, resuspending bacteria in PBS, and diluting to the appropriate concentration. 
E. coli was grown at $37^{\circ} \mathrm{C}$ in Luria-Bertani broth (LB) and on LB agar (LA) [19]. LB was supplemented with ampicillin $(100 \mu \mathrm{g} / \mathrm{mL})$, chloramphenicol $(20 \mu \mathrm{g} / \mathrm{mL})$, kanamycin $(20 \mu \mathrm{g} / \mathrm{mL})$, or sucrose $(10 \%)$ when required.

For growth curves, single colonies of 15 NIIEG and the derivates were grown on FT-agar plates, then prepared a bacterial suspension in BHI broth to an optical density at $600 \mathrm{~nm}\left(\mathrm{OD}_{600}\right)$ of 0.8 . Ten microliters of each culture was added to wells with 190 microliters of BHI broth. Moreover, 96-well culture flat bottom plate with a lid (Costar REF 3599, Corning, NY, USA) was used for cultivation in Multiscan FC unit (Thermo scientific) at $37^{\circ} \mathrm{C}$ with shaking $100 \mathrm{rpm} / \mathrm{min}$ for $24 \mathrm{~h}$. $\mathrm{OD}_{600}$ was recorded in wells at one-hour intervals.

DNA manipulations. To isolate plasmid DNA from E. coli cells, plasmid-transform E. coli cells, and perform genetic engineering, we followed the guidelines in [20]. Plasmid DNA from F. tularensis was isolated as described earlier in [21]. F. tularensis DNA was isolated with the GenElute ${ }^{\mathrm{TM}}$ Bacterial Genomic DNA Kit (Sigma-Aldrich, Moscow, Russia). F. tularensis whole-genome sequencing was performed using the Illumina MiSeq instrument according to the manufacturer's instruction. MiSeq Reagent Kit v3 (300 cycles) was used for sequencing.

Interspecies conjugation. Plasmids were transferred from E. coli S17-1 cells into F. tularensis cells as described in [11,22] and modified as follows: $50 \mu \mathrm{L}$ of a suspension of the donor E. coli S17-1 strain with the mobilized plasmid $\left(1 \times 10^{8}\right.$ cells $)$ was mixed with $50 \mu \mathrm{L}$ of the recipient $F$. tularensis strain $\left(3 \times 10^{10}\right.$ cells), and was spotted $10 \mu \mathrm{L}$ on LB agar. The cultures were then incubated at $25^{\circ} \mathrm{C}$ over $20 \mathrm{~h}$ and seeded onto FT agar containing $100 \mu \mathrm{g} / \mathrm{mL}$ of polymyxin B and $1 \mu \mathrm{g} / \mathrm{mL}$ of chloramphenicol to select F. tularensis clones with the cat gene of plasmid. Petri dishes were incubated 5 days at $37^{\circ} \mathrm{C}$.

Cryotransformation of F. tularensis bacteria by plasmid DNA. Overnight agar culture was suspended in $10 \mathrm{~mL}$ of FTB.: The suspension was cultivated in a shaker at $37{ }^{\circ} \mathrm{C}$ and $200 \mathrm{rpm}$ over $2.5 \mathrm{~h}$ and concentrated by centrifugation. Centrifugation sediment was suspended in $80 \mu \mathrm{L}$ of the transformation buffer TB $\left(0.1 \mathrm{M} \mathrm{MgSO}_{4}, 10 \mathrm{mM}\left(\mathrm{NH}_{4}\right)_{2}\right.$ $\left.\mathrm{SO}_{4}, \mathrm{pH} 7.5\right)$.

For cryotransformation, $2 \mu \mathrm{L}$ of the DNA solution was mixed with $20 \mu \mathrm{L}$ of the bacterial suspension in a $250-\mu \mathrm{L}$ microtube, and incubated over $10 \mathrm{~min}$ at room temperature. Then the tube was cooled down in liquid nitrogen over $5 \mathrm{~min}$ and heated to $37^{\circ} \mathrm{C}$ over $10 \mathrm{~min}$. The suspension was inoculated into $500 \mu \mathrm{L} \mathrm{FTB}$, incubated at $37^{\circ} \mathrm{C}$ over $2 \mathrm{~h}$ and plated onto the selective FT agar containing selective antibiotic [23].

Design of $p H V m o b$ plasmid. pHV33 plasmid DNA was digested with BamHI and ligated with 1.7-kb Bam HI fragment with a mob region of pPV plasmid [11]. Recombinant plasmid was transformed into E. coli $\mathrm{DH} 5 \alpha$. The clones with $\sim 8.9-\mathrm{kb} \mathrm{pHVmob}$ plasmid were selected on LA with chloramphenicol. Functional activity of the mob region in $\mathrm{pHVmob}$ was tested

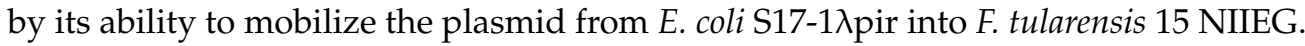

Design of bireplicon vector pUK194. pUK194 with amp and kan genes was constructed as result of ligation of plasmids pK194 and pUC19 digested with HindIII.

pK194 was developed on base of modified pHV33 plasmid carrying kan gene from mTn10Km transposon instead cat gene. pHV33Km was selected after insertion mTn10Km transposon in F. tularensis 15(pHV33). pHV33Km was digested with HindIII, 2.9-kb fragment gel purified and ligated. Plasmid (pK194) obtained contains kan gene and is capable of autonomously replication in F. tularensis 15 NIIEG.

recD deletion in F. tularensis 15 NIIEG genome.

Design of suicide plasmid for recD deletion. pGM $\Delta$ recD plasmid was create on base of pGM5 vector [16] (Figure 1). 


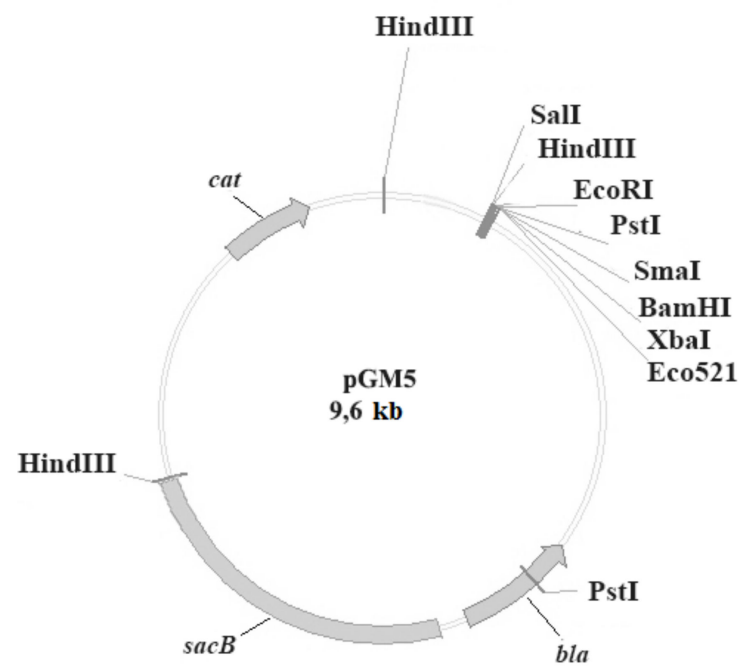

Figure 1. pGM5 plasmid.

$\mathrm{FSD} / \mathrm{RBD}$ and FBD/RSD primers were used for synthesis of two amplicons adjacent to the recD F. tularensis gene and sized $1433 \mathrm{bp}\left(5^{\prime}\right.$ left arm) and $1462 \mathrm{bp}$ ( $3^{\prime}$ right arm). The amplicons were hydrolyzed with SalI and BamHI and ligated with Sall linearized and dephosphorylated pGM5. The mixture after ligation was transformed the E. coli DH5 $\alpha$. Clones with pGM $\Delta \mathrm{recD}$ plasmid were selected on $A m{ }^{R}{ }^{R} m^{R} S u c^{S}$ phenotype and by PCR on the FCD/RCD primers.

Allelic replacement of recD gene. Broth culture of $F$. tularensis with integrated $\mathrm{pGM} \Delta \mathrm{recD}$ was incubated at $37^{\circ} \mathrm{C}$ over $6 \mathrm{~h}$, then plated onto FT agar with added $5 \%$ sucrose and polymyxin $\mathrm{B}$ and continued incubation at $37^{\circ} \mathrm{C}$ over 3 days for selection of Suc ${ }^{\mathrm{R}}$ clones. The clones were checked on $\mathrm{Cm}^{\mathrm{S}}$ phenotype on FT agar with $\mathrm{Cm}(1 \mu \mathrm{g} / \mathrm{mL})$. and presence only genome region without recD gene using FCD/RCD and FSD/RSD primers.

Creation of plasmid with recD gene ( $p U K / r e c D)$ for complementation. A 3498-kb amplicon with the recD gene was created by PCR on FSD/RSD primers and F. tularensis 15 NIIEG DNA, hydrolyzed with SalI and ligated in Sall site of pUK194. The ligate was used to transform E. coli DH5 $\alpha$ cells. Presence of $F$. tularensis recD gene in $A m p^{R} \mathrm{Km}^{\mathrm{R}}$ transformants was checked by PCR on FSD/RSD and FCD/RCD primers.

Design of suicide plasmid for sodC deletion. pGM $\Delta$ sodC plasmid was create on base of pGM5. sodCL-F/sodCL and sodCR-F/sodCR-R primers were used for synthesis of two amplicons adjacent to the sodC F. tularensis gene and sized $937 \mathrm{bp}\left(5^{\prime}\right.$ left arm) and $745 \mathrm{bp}$ ( $3^{\prime}$ right arm). The amplicons were hydrolyzed with SalI and BamHI and ligated with SalI linearized and dephosphorylated pGM5. The mixture after ligation was transformed the E. coli $\mathrm{DH} 5 \alpha$. Clones with $\mathrm{pGM} \Delta \operatorname{sodC}$ plasmid were selected on $A m p{ }^{R} C^{R}{ }^{R} u c^{S}$ phenotype and by PCR on the sodC-KF/sodC-KR primers.

Testing F. tularensis strains' capacity for homologous recombination. F. tularensis $15 \mathrm{NI}-$ IEG, 15D, 15D(pUK/recD, and 15D(pUK194) strains were tested for their capacity for homologous recombination of $\mathrm{pPV} / \triangle i g l C$ [11] and $\mathrm{pGM} \Delta$ sodC suicide plasmids. With this purpose $\mathrm{pPV} / \triangle i g l C$ was mobilized from E. coli S17-1 into F. tularensis, and $\mathrm{pPV} / \Delta i g l C$ was cryotransformated into $F$. tularensis. pHVmob plasmid autonomous replicating in F. tularensis and capable of mobilizing from E. coli S17-1 into F. tularensis was used as control for efficiency of plasmids transfer.

Infection of macrophages. The murine macrophage line J774A.1 from the Russian Collection of Cell Cultures, St. Petersburg was used. $1 \times 10^{5}$ cells were seeded into wells of in 24-well tissue culture plates (Costar, Corning, NY, USA) and incubated in Dulbecco's modified Eagle's medium (DMEM; GIBCO BRL, Grand Islands, NY, USA) supplemented with $10 \%$ fetal bovine serum and $2 \mathrm{mM}$ L-glutamine at $37^{\circ} \mathrm{C}$ in humidified air containing $5 \% \mathrm{CO}_{2} .24 \mathrm{~h}$. F. tularensis suspension was inoculated in the wells with macrophages 
monolayer at a multiplicity of infection 100:1. After incubation for $2 \mathrm{~h}$ at $37^{\circ} \mathrm{C}$, wells were washed with PBS to remove extracellular bacteria. Macrophages were reconstituted in culture medium supplemented with $2 \mu \mathrm{g} / \mathrm{mL}$ of gentamicin and incubated for the indicated periods of time. Then, the infected macrophages were lysed with $0.5 \mathrm{~mL}$ of $0.05 \%$ dodeoxycholate and the number of CFU determined by plating serial 10-fold dilutions on FT agar medium.

Animal infections. All animal studies were conducted at the Protocol Number VP2021/4 from 23.09.2021 of the SRCAMB Bioethics Committee in accordance with the Good Animal Care requirements [24]. Six- to 8-week-old BALB/c mice (Institute of Bioorganic Chemistry, Russian Academy Sciences in Pushchino, Russian Federation) were infected subcutaneously (s.c.) in a final volume of $0.2 \mathrm{~mL}$ with F. tularensis 15 NIIEG derivatives. Challenge doses per mouse were from $1 \times 10^{2}$ to $1 \times 10^{5} \mathrm{CFU}$ (five mice per one dose).

Statistical Analyses. All values were expressed as means \pm standard errors of the means. One-way analysis of variance (ANOVA), followed by a post hoc test (Bonferroni) and a one-tailed Student $t$ test, was used to identify differences between groups.

\section{Results and Discussion}

\subsection{Comparative Analysis of Amino Acid Sequences RecD Proteins in the Genus Francisella}

The amino acid sequences of in strains of different species and subspecies of the genus Francisella have some differences. RecD protein F. philomiragia and F. tularensis subsp. novicida, in comparison with other subspecies of the tularemia microbe, has an extended deletion of 22 aa. At the N-terminus of the RecD protein in F. tularensis subsp. holarctica and F. philomiragia, there is a 9 amino acid deletion, which distinguishes these species from others. There are 28 amino acid substitutions and a deletion of 22 amino acid residues in the RecD protein of F. tularensis subsp. novicida in comparison with other subspecies of the tularemia microbe. The amino acid sequences of the RecD proteins of $F$. philomiragia differ in 47 amino acid residues from RecD of subspecies of F. tularensis (Supplementary S3).

\section{2. recD Deletion in F. tularensis 15 NIIEG Genome}

The recD deletion variant of $F$. tularensis 15 NIIEG was obtained using the suicide plasmid pGM $\Delta \mathrm{recD}$, created on the basis of the pGM5 vector, consisting of the pBR22 plasmid and the modified pC194 plasmid, which lost the ability to replicate in F. tularensis [16]. Plasmid pGM $\Delta$ recD was introduced into F. tularensis 15 NIIEG cells by cryotransformation. Clones carrying pGM $\Delta \mathrm{recD}$ were selected on FT-agar with chloramphenicol $(1 \mu \mathrm{g} / \mathrm{ml})$. The presence of sacB gene in the clones was detected by the inhibition of culture growth on FT-agar with the addition of $10 \%$ sucrose. FCD/RCD primers were used for a check of presence of both native and modified recD gene in the clones. As a result of allelic exchange, clones with the $\mathrm{Cm}^{\mathrm{S}} \mathrm{Suc}^{\mathrm{R}}$ phenotype were selected, containing only a modified region of the genome without the recD gene. Amplicon obtained with FCD/RCD primers on the modified strain 15D DNA was $0.6 \mathrm{~kb}$ shorter than it on parent strain DNA (Figure 2, Supplementary S4).

F. tularensis $15 \mathrm{D}$ was free from selection markers of $\mathrm{pGM} \Delta \mathrm{recD}$ suicide plasmid, such as chloramphenicol resistance or sucrose sensitivity. Comparison of nucleotide sequences of recD regions of F. tularensis 15D and 15 NIIEG strains showed that the modified strain to have 604 nucleotides deletion. No nucleotide substitutions found in the $\operatorname{rec} B$ and $\operatorname{rec} C$ genes adjacent to recD, see Supplementary S5. 


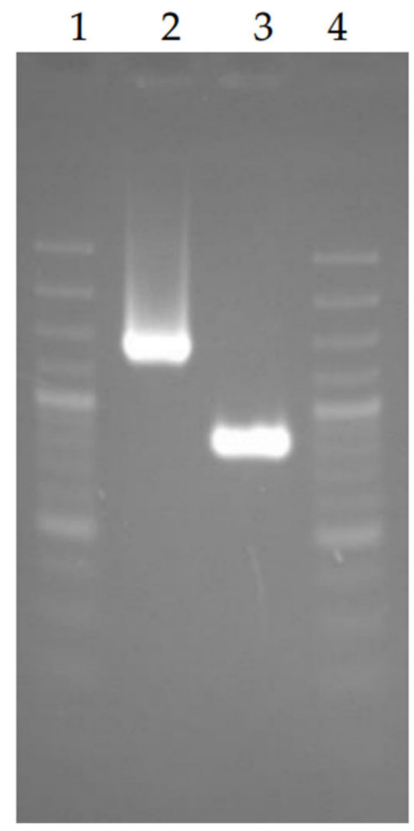

Figure 2. PCR analysis with FCD/RCD primers of F. tularensis DNA: 15 NIIEG-line 2, 15D—line 3. 100 bp plusDNA ladder (Fermentas)-lines 1 and 4.

\subsection{Effects of recD on Homologous Recombination in F. tularensis}

To study the effects of the recD gene on homologous recombination in F. tularensis, we tested the F. tularensis $15 \mathrm{D}$ strain and its derivatives: $15 \mathrm{D}(\mathrm{pUK} / \mathrm{recD})$ with $\mathrm{pUK} / \mathrm{recD}$ plasmid carrying genome fragment with the recD gene; and 15D(pUK194) with pUK194 vector plasmid. The homologous recombination event was assessed by the appearance of clones resistant to chloramphenicol as a result of transfer of suicide plasmids carrying F. tularensis DNA fragments. pPV $\Delta$ iglC plasmid integration efficiency into the $F$. tularensis $15 \mathrm{D}$ and $15 \mathrm{D}$ (pUK194) chromosomes by mobilization from E. coli S17-1 was significantly lower than it for parent strain 15 NIIEG, see Table 3. The same result was obtained for $\mathrm{pGM} \Delta$ sodC plasmid which was transformed F. tularensis $15 \mathrm{D}$ and $15 \mathrm{D}$ (pUK194). The phenomenon of homologous recombination with the participation of the suicide plasmids in strain 15 NIIEG was confirmed by the fact that the transfer of vectors (pPV and pGM5) did not lead to the appearance of $\mathrm{Cm}^{\mathrm{R}}$ clones. Transformation of $\mathrm{pUK} / \mathrm{recD}$ plasmid into the 15D strain restored the suicide plasmids integration capacity to the same level of efficiency as in the parent strain 15 NIIEG, see Table 3.

Table 3. Efficiency of the integration of $\mathrm{pPV} \Delta \mathrm{iglC}$ and $\mathrm{pGM} \Delta \operatorname{sodC}$ suicide plasmids into $F$. tularensis chromosomes.

\begin{tabular}{|c|c|c|}
\hline \multirow{2}{*}{ F. Tularensis Strain } & \multicolumn{2}{|c|}{$\mathrm{Cm}^{\mathrm{R}}$ Clones Per Recipient Cell } \\
\hline & $\mathrm{pPV} / \Delta \mathrm{iglC}$ & $\mathrm{pGM} / \Delta \operatorname{sodC}$ \\
\hline $15 \mathrm{D}$ & $<1 \times 10^{-9}$ & $<1 \times 10^{-9}$ \\
\hline 15 NIIEG & $1 \times 10^{-7}$ & $1 \times 10^{-6}$ \\
\hline $15 \mathrm{D}(\mathrm{pUK} / \mathrm{recD})$ & $1 \times 10^{-6}$ & $1 \times 10^{-6}$ \\
\hline 15D(pUK194) & $<1 \times 10^{-9}$ & $<1 \times 10^{-9}$ \\
\hline
\end{tabular}

The modified strains practically did not differ from 15 NIIEG in their ability to mobilize $\left(\sim 1 \times 10^{7} \mathrm{CFU}\right)$ and transform $\left(\sim 1 \times 10^{6} \mathrm{CFU}\right.$ per $\mu \mathrm{g}$ of DNA $)$ in experiments with the pHVmob plasmid that replicating autonomously into F. tularensis (Table 4). 
Table 4. Efficiency of the transfer of pHVmob plasmid into F. tularensis strains.

\begin{tabular}{ccc}
\hline \multirow{2}{*}{ F. Tularensis Strain } & \multicolumn{2}{c}{ Cm $^{\mathrm{R}}$ Clones Per Recipient Cell } \\
\cline { 2 - 3 } & $\begin{array}{c}\text { Mobilization Efficiency } \\
\text { (Per Recipient Cell) }\end{array}$ & $\begin{array}{c}\text { Cryotransformation } \\
\text { Efficiency (CFU } \mu \mathrm{g} \text { DNA) }\end{array}$ \\
\hline 15D & $3 \times 10^{-2}$ & $1 \times 10^{6}$ \\
15 NIIEG & $3 \times 10^{-2}$ & $1 \times 10^{6}$ \\
15D (pUK/recD) & $3 \times 10^{-2}$ & $1 \times 10^{6}$ \\
15D (pUK194) & $3 \times 10^{-2}$ & $1 \times 10^{6}$ \\
\hline
\end{tabular}

\subsection{Growth of F. tularensis $15 D$ in Nutrient Media and J774.1A Cells}

Comparative analysis of $F$. tularensis $15 \mathrm{D}$ colonies sizes on chocolate agar after 3 days of culturing at $37^{\circ} \mathrm{C}$ showed that modified strain colonies were smaller $F$. tularensis 15 NIIEG one, see Figure 3.

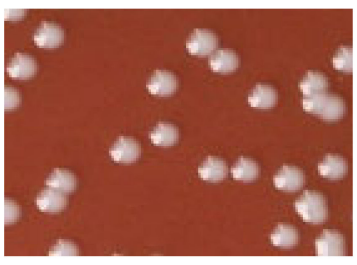

(A)

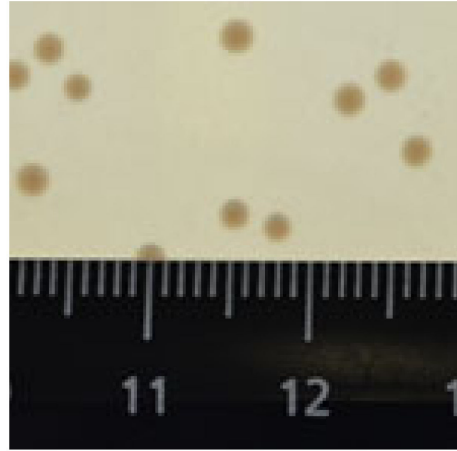

(C)

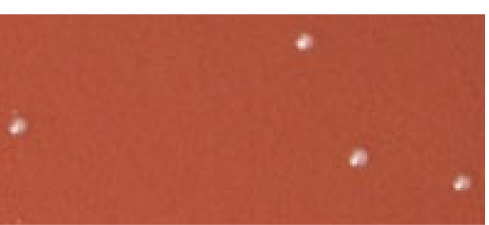

(B)

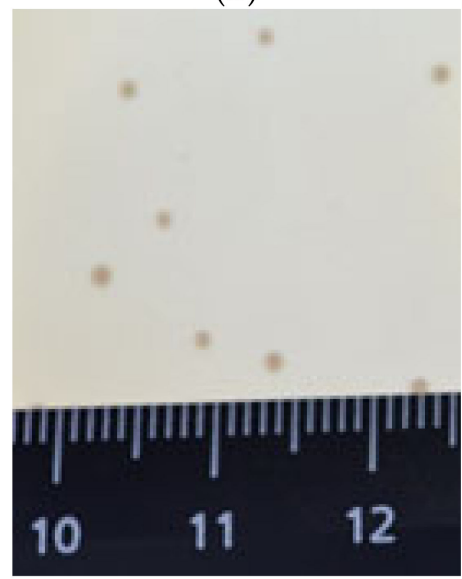

(D)

Figure 3. F. tularensis colonies morphology on chocolate agar (A,B), FT-agar (C,D): 15 NIIEG (A,C) and $15 \mathrm{D}(\mathbf{B}, \mathbf{D})$.

Slower growth of $F$. tularensis 15D in comparisio with 15 NIIEG was observed in BHI medium, see Figure 4A. Transcomplementation of the recD deletion in F. tularensis 15D with $\mathrm{pUK} / \mathrm{recD}$ restored speed growth in comparison to the $15 \mathrm{D}$ (pUK194), carrying only plasmid vector, see Figure 4B. 


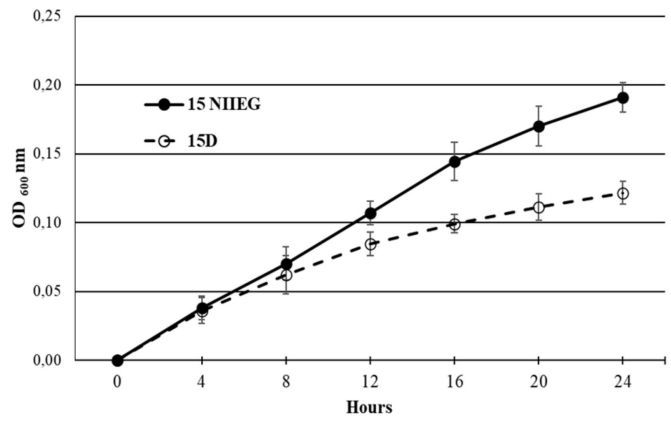

(A)

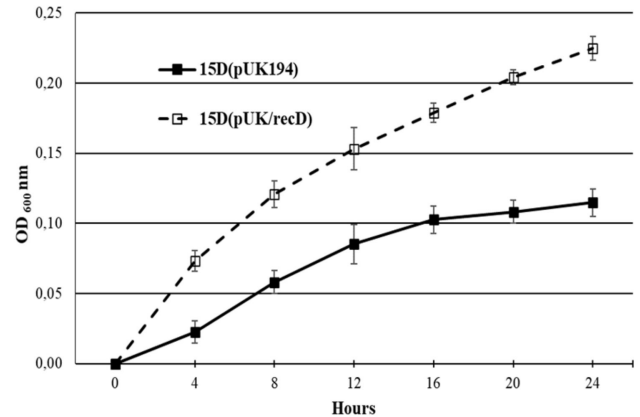

(B)

Figure 4. F. tularensis growth in BHI broth at $37^{\circ} \mathrm{C}$, strains: (A)-15D and 15 NIIEG; (B)-15D (pUK/recD) and 15D (pUK194).

F. tularensis $15 \mathrm{D}$ bacteria, aside from reduced growth in vitro, had reduced reproduction ability in J774.1A cells compared to the 15 NIIEG strain, see Figure 5.

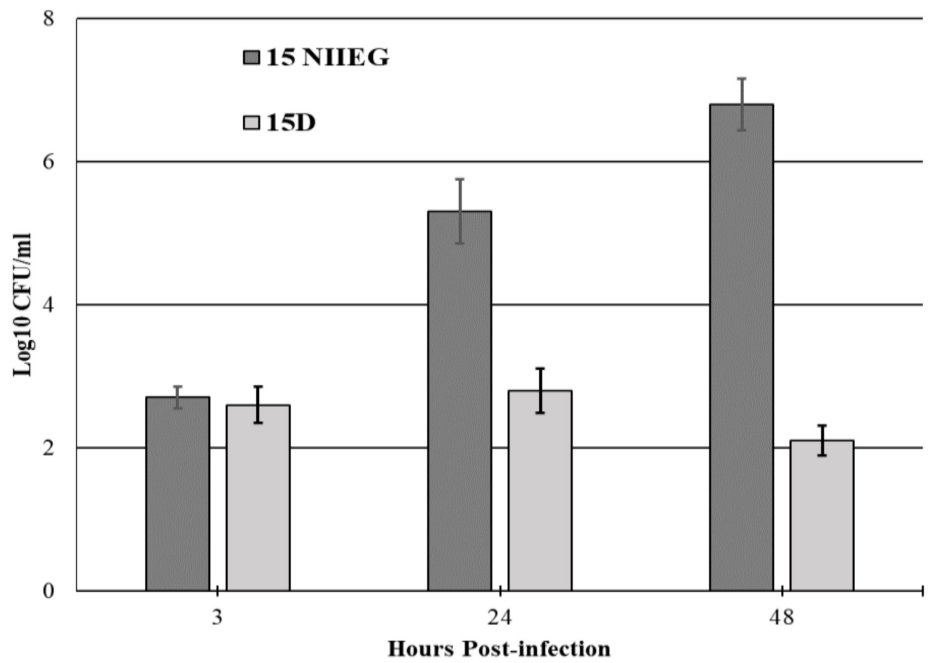

Figure 5. Effect of $r e c D$ deletion on F. tularensis reproduction in J774.1A cells. 15 NIIEG strain was used as control. Macrophages were infected with bacteria at a ratio of 100:1. The macrophages were lysated at 3, 24, and $48 \mathrm{~h}$ upon infection. The diagram shows the average results of the number of colonies on FT agar as $\mathrm{Lg} \mathrm{CFU} / \mathrm{mL} \pm$ confidence interval $(p<0.05)$ obtained in three independent experiments.

\section{5. recD Deletion Effects on F. tularensis Virulence}

F. tularensis $15 \mathrm{D}$ without $\mathrm{rec} D$ gene had significantly reduced virulence for BALB/c mice infected s.c. in comparison with 15 NIIEG, see Table 5.

Table 5. BALB/c mice survival after s.c. F. tularensis challenge.

\begin{tabular}{ccc}
\hline F. Tularensis Strain & Challenge Dose & Survival (\%) \\
\hline \multirow{2}{*}{$15 \mathrm{D}$} & $1 \times 10^{3}$ & 100 \\
& $1 \times 10^{5}$ & 100 \\
$15 \mathrm{D}(\mathrm{pUK} / \mathrm{recD})$ & $8 \times 10^{2}$ & 0 \\
& $8 \times 10^{4}$ & 0 \\
$15 \mathrm{D}(\mathrm{pUK194})$ & $6 \times 10^{2}$ & 100 \\
& $6 \times 10^{4}$ & 100 \\
$15 \mathrm{NIIEG}$ & $1 \times 10^{2}$ & 30 \\
& $1 \times 10^{3}$ & 0 \\
\hline
\end{tabular}


Transcomplementation of the recD deletion in F. tularensis $15 \mathrm{D}$ with $\mathrm{pUK} / \mathrm{recD}$ increased virulence in comparison to the 15D and 15D (pUK194), carrying only plasmid vector, see Table 5 .

\section{Discussion}

One of the possible directions for stabilizing and reactogenicity reducing of existing tularemia vaccines is the modification or deletion of genes, the products of which are involved in repair processes and intragenomic rearrangements. Such targets can be $\operatorname{rec} A$ gene [25], $r e c B$ [26], and $r e c D$ gene. The function of RecD protein of $E$. coli, a component multifunctional enzyme RecBCD in nucleic acid exchange, has been studied in detail [27,28]. The F. tularensis LVS genome contains the FTL_0670 gene (Gen Bank NCBI) encoding a protein similar to the $E$. coli RecD protein. An identical nucleotide sequence is also present in the genome of F. tularensis 15 NIIEG (Supplementary S2).

recD gene deletion in strain 15 NIIEG led to a slowdown in bacterial growth on solid and liquid nutrient media, as well as to a slowdown in reproduction in J774.1A macrophagelike cells. The observed decrease in the replication of strain $15 \mathrm{D}$ in macrophages can probably be explained by its reduced ability to grow in the BHI medium, which mimics the growth conditions in macrophages [29-31]. This effect may have led to a significant decrease in the virulence of the modified F. tularensis 15D strain. Influence of the recD gene on bacterial growth was previously demonstrated for Pseudomonas syringae Lz4W [32].

There are extended nucleotide repeats in F. tularensis genomes [33], which could be the reason for genomic rearrangements. To elucidate the $r e c D$ gene role in the process of homologous recombination, the F. tularensis 15 NIIEG strain without the recD gene was created. The recipient properties of 15D strain during interspecies transfer and cryotransformation of autonomous replication in F. tularensis plasmids did not differ from the properties of the parental strain. However, the transfer and integration of suicide plasmids carrying extended F. tularensis genome fragments into 15D strain were significantly suppressed in comparison with strain 15 NIIEG. Transcomplementation of this mutation in 15D strain led to the restoration of suicidal plasmids integration. Thus, the deletion of the recD gene may reduce the likelihood of intragenomic rearrangements in the vaccine strain, which will lead to stabilization of the properties of the tularemia vaccine. The properties of the vaccine strain without the recD gene listed above allow us to hope that this approach is promising for the development of more stable and less reactogenic vaccine strains of F. tularensis.

Supplementary Materials: The following supporting information can be downloaded at: https:/ / www.mdpi.com/article/10.3390/vaccines10010108/s1, Supplementary S1: Structure of the genome regions of $F$. tularensis and E. coli with recBCD genes; Supplementary S2: Comparison of therecBCD regions of Francisella tularensis subsp. holarctica LVS and Francisella tularensis subsp. holarctica 15 NIIEG; Supplementary S3: Multiple alignment of the amino acid sequence of the RecD proteins of the genus Francisella; Supplementary S4: Electrophoregram of amplicons; Supplementary S5: Comparison of therecBCD regions of Francisella tularensis subsp. holarctica LVS and Francisella tularensis subsp. holarctica $15 \mathrm{D}$.

Author Contributions: Conceptualization, V.P., A.M. and M.E.P.; methodology, G.V., G.T., R.M., T.K. and T.G.; formal analysis, V.P. and M.E.P.; investigation, G.V., G.T., R.M., T.K. and T.G.; resources, funding acquisition, and project administration, I.D. and A.M.; writing-original draft preparation, V.P. and A.M.; writing-review and editing, all authors. All authors have read and agreed to the published version of the manuscript.

Funding: This research was funded by the Ministry of Science and Higher Education of the Russian Federation, agreement.075-15-2019-1671 dated 31 October 2019.

Institutional Review Board Statement: All animal studies were conducted at the Protocol Number VP-2021/4 from 23.09.2021 of the SRCAMB Bioethics Committee in accordance with the Good Animal Care requirements.

Informed Consent Statement: Not applicable. 
Data Availability Statement: All data used for this study are available in the text of the article and in the Supplementary Materials.

Acknowledgments: The authors would like to thank Angelina Kislichkina, and Alexandr Bogun for their help in the DNA sequencing.

Conflicts of Interest: The authors declare no conflict of interest.

\section{References}

1. Gill, V.; Cunha, B.A. Tularemia pneumonia. Semin. Respir. Infect. 1997, 12, 61-67. [PubMed]

2. Dennis, D.T.; Inglesby, T.V.; Henderson, D.A.; Bartlett, J.G.; Ascher, M.S.; Eitzen, E.; Fine, A.D.; Friedlander, A.M.; Hauer, J.; Layton, M.; et al. Tularemia as a Biological Weapon: Medical and Public Health Management. J. Am. Med. Assoc. 2001, 285, 2763-2773. [CrossRef] [PubMed]

3. Olsuf'ev, N.G. Taxonomy, Microbiology and Laboratory Diagnosis of the Causative agent of Tularemia; Izd. Meditsina: Moscow, Russia, 1975; 192p. (In Russian)

4. $\quad$ Ellis, J.; Oyston, P.S.F.; Green, M.; Titball, R.W. Tularemia. Clin. Microbiol. Rev. 2002, 15, 631-636. [CrossRef]

5. Medunitsyn, N.V. Vaccinology; Izd. Triada-Kh: Moscow, Russia, 1999; 272p. (In Russian)

6. Eigelsbach, H.T.; Downs, C.M. Prophylactic effectiveness of live and killed tularemia vaccines. I. Production of vaccine and evaluation in the white mouse and guinea pig. J. Immunol. 1961, 87, 415-425. [PubMed]

7. Sandstrom, G. The tularemia vaccine. J. Chem. Technol. Biotechnol. 1994, 59, 315-320. [CrossRef]

8. Conlan, J.W.; Oyston, P.C.F. Vaccines against Francisella tularensis. Ann. N. Y. Acad. Sci. 2007, 1105, 325-350. [CrossRef]

9. Smith, G.R. How RecBCD enzyme and Chi promote DNA break repair and recombination: A molecular biologist's view. Microbiology and molecular biology reviews. Microbiol. Mol. Biol. Rev. 2012, 76, 217-228. [CrossRef]

10. Woodcock, D.M.; Crowther, P.J.; Doherty, J.; Jefferson, S.; DeCruz, E.; Noyer-Weidner, M.; Smith, S.S.; Michael, M.Z.; Graham, M.W. Quantitative evaluation of Escherichia coli host strains for tolerance to cytosine methylation in plasmid and phage recombinants. Nucleic Acids Res. 1989, 17, 3469-3478. [CrossRef] [PubMed]

11. Golovliov, I.; Sjostedt, A.; Mokrievich, A.; Pavlov, V. A method for allelic replacement in Francisella tularensis. FEMS Microbiol. Lett. 2003, 222, 273-280. [CrossRef]

12. Iordanescu, S. Recombinant plasmid obtained from two different, compatible staphylococcal plasmids. J. Bacteriol. 1975, 124, 597-601. [CrossRef] [PubMed]

13. Horinouchi, S.; Weisblum, B. Nucleotide sequence and functional map of pC194, a plasmid that specifies inducible chloramphenicol resistance. J. Bacteriol. 1982, 150, 815-825. [CrossRef] [PubMed]

14. Pomerantsev, A.P.; Domaradskii, I.V.; Doronin, I.P.; Fursov, V.V. Investigation of cat-gene expression of plasmids Sa and pC194 in Escherichia coli, Francisella tularensis and Bacillus subtilis cells. Mol. Gen. Mikrobiol. Virusol. 1991, 9, 21-24. (In Russian) [PubMed]

15. Primrose, S.B.; Ehrlich, S.D. Isolation of plasmid deletion mutants and study of their instability. Plasmid 1981, 6, 193-201. [CrossRef]

16. Mokrievich, A.N.; Vakhrameeva, G.M.; Titareva, G.M.; Bakhteeva, I.V.; Mironova, R.I.; Kombarova, T.I.; Kravchenko, T.B.; Dyatlov, I.A.; Pavlov, V.M. Construction and characterization of Francisella tularensis vaccine strain with a single copy of $i g l C$ gene and lacking recA gene. Mol. Gen. Microbiol. Virol. 2015, 30, 148-156. [CrossRef]

17. Yanisch-Perron, C.; Vieira, J.; Messing, J. Improved M13 phage cloning vectors and host strains: Nucleotide sequences of the M13mp18 and pUC19 vectors. Gene 1985, 33, 103-119. [CrossRef]

18. Bakshi, C.S.; Malik, M.; Regan, K.; Melendez, J.A.; Metzger, D.W.; Pavlov, V.M.; Sellati, T.J. Superoxide dismutase B gene (sodB)deficient mutants of Francisella tularensis demonstrate hypersensitivity to oxidative stress and attenuated virulence. J. Bacteriol. 2006, 188, 6443-6448. [CrossRef]

19. Miller, D. Experiments in Molecular Genetics; Cold Spring Harbor Laboratory: Cold Spring Harbor, NY, USA, 1972.

20. Sambrook, J.; Fritsch, E.F.; Maniatis, T. Molecular Cloning: A Laboratory Manual, 2nd ed.; Cold Spring Harbor Laboratory Press: Cold Spring Harbor, NY, USA, 1989.

21. Pavlov, V.M.; Mokrievich, A.N.; Volkovoy, K. Cryptic plasmid pFNL10 from Francisella novicida-like F6168, The base of plasmid vectors for Francisella tularensis. FEMS Immunol. Med. Microbiol. 1996, 13, 253-256. [CrossRef] [PubMed]

22. Mokrievich, A.N.; Vakhrameeva, G.M.; Mironova, R.I.; Kombarova, T.I.; Titareva, G.M.; Kravchenko, T.B.; Bakhteeva, I.V.; Dyatlov, I.A.; Pavlov, V.M. Construction and Investigation of the Vaccine Strain Francisella tularensis without iglC genes. Commun. 1. Probl. Osobo Opasnykh Inf. 2013, 117, 70-74. (In Russian) [CrossRef]

23. Shishkova, N.A.; Vakhrameyeva, G.M.; Pavlov, V.M.; Mokrievich, A.N.; Dyatlov, I.A. Plazmida cryotransformation of vaccin strain Francisella tularensis 15 NIIEG. Bacteriology 2018, 3, 38-42. (In Russian) [CrossRef]

24. National Research Council. Guide for the Care and Use of Laboratory Animals, 8th ed.; National Academy Press: Washington, DC, USA, 2010; 220p.

25. Lapin, A.A.; Mokrievich, A.N.; Vakhrameeva, G.M.; Kombarova, T.I.; Bakhteeva, I.V.; Dyatlov, I.A.; Pavlov, V.M. Immunobiological properties of Francisella tularensis 15/10 strain with deleted recA gene. Probl. Osobo Opasn. Infekts. 2011, 110, 65-67. (In Russian) [CrossRef] 
26. Cano, D.A.; Pucciarelli, M.G.; Portillo, F.G.; Casadesús, J. Role of the RecBCD Recombination Pathway in Salmonella Virulence. J. Bacteriol. 2002, 184, 592-595. [CrossRef] [PubMed]

27. Amundsen, S.K.; Taylor, A.F.; Smith, G.R. The RecD subunit of the Escherichia coli RecBCD enzyme inhibits RecA loading, homologous recombination, and DNA repair. Proc. Natl. Acad. Sci. USA 2000, 97, 7399-7404. [CrossRef] [PubMed]

28. Taylor, A.F.; Smith, G.R. RecBCD enzyme is a DNA helicase with fast and slow motors of opposite polarity. Nature 2003, 423, 889-893. [CrossRef]

29. Hazlet, K.R.O.; Caldon, S.D.; McArthur, D.G.; Cirillo, K.A.; Kirimanjeswara, G.S.; Magguilli, M.L.; Malik, M.; Shah, A.; Broderick, S.; Golovliov, I.; et al. Adaptation of Francisella tularensis to the mammalian environment is governed by cues which can be mimicked in vitro. Infect. Immun. 2008, 76, 4479-4488. [CrossRef] [PubMed]

30. Hazlet, K.R.O.; Cirillo, K.A. Environmental adaptation of Francisella tularensis. Microbes. Infect. 2009, 11, 828-834. [CrossRef]

31. Holland, K.M.; Rosa, S.J.; Kristjansdottir, K.; Wolfgeher, D.; Franz, B.J.; Zarrella, T.M.; Kumar, S.; Sunagar, R.; Singh, A.; Bakshi, C.S.; et al. Differential growth of Francisella tularensis, which alters expression of virulence factors, dominant antigens, and surface-carbohydrate synthases, governs the apparent virulence of Ft SchuS4 to immunized animals. Front. Microbiol. 2017, 8, 1158. [CrossRef] [PubMed]

32. Regha, K.; Satapathy, A.K.; Ray, M.K. RecD Plays an Essential Function During Growth at Low Temperature in the Antarctic Bacterium Pseudomonas syringae Lz4W. Genetics 2005, 170, 1473-1484. [CrossRef]

33. Larsson, P.; Oyston, P.C.F.; Chain, P.; Chu, M.C.; Duffield, M.; Fuxelius, H.-H.; Garcia, E.; Hälltorp, G.; Johansson, D.; Isherwood, K.E.; et al. The complete genome sequence of Francisella tularensis the causative agent of tularemia. Nat. Genet. 2005, 37, 153-159. [CrossRef] 